\title{
Physiological studies of some chelating agents in accumulation of some heavy metals in Tilapa florida
}

\author{
Abdel-Salam M. Ibraik Ohaida
}

Zoology Department. Faculty of Science. University of Misurata Libya.

\section{ABSTRACT}

The three chelating agents. EDTA. Thiamin and Ascorbic acid were tested for balance and tissue distribution of four essential trace elements, copper. Zinc, iron and manganese, blood, liver kidney and muscle in Tilapia florida. Essential trace element balance was less affected by thiamin administration. Thiamin produced minimum alterations in the tissue levels of essential trace elements. Alterations produced by EDTA were more pronounced than those occurred with ascorbic acid and thiamin. Copper, zinc and iron levels in all tissues were drastically depleted by EDTA. The present results suggested that thiamin had the best efficacy as a metal chelating agent.

Keyword: Tilapa florida, heavy metals, ascorbic acid, thiamin, EDTA

\section{INTRODUCTION}

The therapeutic mechanism of chelating agents involves their interaction with toxic metals leading to their rapid excretion from the body. However, because of their affinity for various metal ions, the potential interaction between these chelating agents and endogenous trace metals is of concern (Cantilena and Klaassen, 1982; Tandon et al., 1984). Thus the toxic manifestations of chelating agents may partly be the result of their interaction with essential metal which may ultimately lead to various characteristic biochemical and pathological alterations (Sigel, 1983). Therefore, it was considered of interest to evaluate the potential of chelating agents to modify the balance and distribution of essential trace elements. The objective of this study was to compare the acute influences of thoursee chelating agents EDTA, thiamin and ascorbic acid on the balance and concentrations of four essential trace elements; copper, zinc, iron and manganese in the different tissues of Tilapia florida.

Contamination of marine water with heavy metals on local, regional and global scales have been intensively studies in recent years, due to the fact that metals are persistent, toxic tend to biaccumulate, and they pose a risk to marine species, diversity, human and ecosystems (Rainbow 2015).

\section{MATERIALS AND METHODS}

Tilapia florida were collected from the Tawarga pond at Misurata Libya. Weighing 100-110g. The fish were immediately transported after catching to special aquaria in the laboratory filled with aerated fresh water. The water temperature was adjusted thermostatically at $22 \pm 0.05^{\circ} \mathrm{C}$. Continuous aeration thoursough aerators were maintained thoursoughout the experimental period. Commercial fish pellets were used as food. Feeding was stopped 24 hours before and during the experimental period.

The acclimated fish were divided into four groups consisting of 32 in each. The animals of each of the first thoursee groups received a concentration of 3.8, 3.4 or 0.6 ppm of EDTA, thiamin or ascorbic acid (Sigma) respectively. The concentrations of 
the chelating agents were selected because none of the fish died over a period of 14 days due to these levels. The fourth group of fish served as a control. Because the fish were not fed during the experimental period, treatments were terminated after 4 days to preclude potential nutritional stresses.

Metal analysis; Six surviving fishes from each group were selected, sacrificed and analyzed for essential trace elements at 24, 48, 72 and 96hours after treatment. Samples of blood, liver, kidney and muscle were obtained from each fish. Blood was collected in heparinized vials by heart puncture, and centrifuged at $2500 \mathrm{rpm}$ for 5 min. plasma protein samples $(0.3 \mathrm{ml})$ were precipitated with $1.5 \mathrm{ml}$ of $6 \%$ trichloroacoetic acid and metals were determined in the resulting supernatant. The other collected tissues (liver, kidney and muscle) were dried at $105^{\circ} \mathrm{C}$ for 48 hours, and digested until clear in reagent grade Nitric acid. The digests were diluted to 100 $\mathrm{ml}$ using bidistilled water. Metal levels in all types of tissues were determined by Atomic Absorption Analyses using a shimadzw A.A. 630-11 Atomic Absorption Spectrophotometer (Langmyher and Amodt, 1976).

Statistical analysis: Values are prseated as means \pm SD of six individual observations. The means of the test and control groups were compared using student's t-test for comparing the means of experimental and control groups. The results were statistically different when $\mathrm{P}<0.05$ by using the software package spee, version 21 (Spssinc. Chicago. IL, USA).

\section{RESULTS}

The effects of acute administration of thoursee chelating agents, EDTA, thiamin and ascorbic acid, on the tissue levels of four endogenous essential trace elements, copper, zinc, iron and manganese at various time intervals are shown in Tables (1-4).

Table 1: Comparative influences of EDTA, thiamin and ascorbic acid on the blood levels of essential trace elements at 24, 48, 72 and 96hours after treatment.

\begin{tabular}{|c|c|c|c|c|c|}
\hline \multirow{2}{*}{$\begin{array}{c}\text { Chelating } \\
\text { agent }\end{array}$} & \multirow{2}{*}{$\begin{array}{l}\text { Time interval } \\
\text { (hours) }\end{array}$} & \multicolumn{4}{|c|}{ Element level (ug/g dry weight ) } \\
\hline & & Copper & Zinc & Iron & Manganese \\
\hline Control & & $0.18 \pm 0.04$ & $0.91 \pm 0.15$ & $2.83 \pm 0.27$ & $0.06 \pm 0.03$ \\
\hline \multirow{4}{*}{ 占 } & 24 & $0.16 \pm 0.05$ & $0.84 \pm 0.27$ & $2.41 \pm 0.98$ & $0.10 \pm 0.05$ \\
\hline & 48 & $0.13 \pm 0.09$ & $0.72 \pm 0.29$ & $2.53 \pm 0.89$ & $0.08 \pm 0.02$ \\
\hline & 72 & $0.11 \pm 0.04^{*}$ & $0.57 \pm 0.11^{*}$ & $2.44 \pm 0.22 *$ & $0.07 \pm 0.05$ \\
\hline & 96 & $0.11 \pm 0.03 *$ & $0.59 \pm 0.21 *$ & $1.72 \pm 0.38 *$ & $0.05 \pm 0.04$ \\
\hline \multirow{4}{*}{. } & 24 & $0.17 \pm 0.12$ & $0.89 \pm 0.61$ & $2.79 \pm 1.11$ & $0.07 \pm 0.03$ \\
\hline & 48 & $0.16 \pm 0.06$ & $0.91 \pm 0.58$ & $2.74 \pm 1.02$ & $0.06 \pm 0.02$ \\
\hline & 72 & $0.17 \pm 0.10$ & $0.91 \pm 0.41$ & $2.80 \pm 1.14$ & $0.06 \pm 0.01$ \\
\hline & 96 & $0.17 \pm 0.04$ & $0.87 \pm 0.52$ & $2.77 \pm 1.06$ & $0.04 \pm 0.03$ \\
\hline \multirow{4}{*}{ 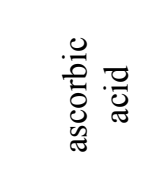 } & 24 & $0.17 \pm 0.08$ & $0.86 \pm 0.39$ & $2.59 \pm 1.39$ & $0.09 \pm 0.06$ \\
\hline & 48 & $0.15 \pm 0.13$ & $0.89 \pm 0.60$ & $2.61 \pm 0.86$ & $0.09 \pm 0.05$ \\
\hline & 72 & $0.14 \pm 0.05$ & $0.87 \pm 0.11$ & $2.53 \pm 0.27$ & $0.06 \pm 0.03$ \\
\hline & 96 & $0.16 \pm 0.15$ & $0.71 \pm 0.99$ & $2.03 \pm 0.33 *$ & $0.08 \pm 0.05$ \\
\hline
\end{tabular}

$\mathrm{P}<0.05$, relative to control

Table 2: Comparative influences of EDTA, thiamin and ascorbic acid on the liver levels of essential trace elements at 24, 48, 72 and 96hours after treatment.

\begin{tabular}{|l|c|c|}
\hline Chelating & Time interval & Element level (ug/g dry weight ) \\
\hline
\end{tabular}




\begin{tabular}{|c|c|c|c|c|c|}
\hline agent & (hours) & Copper & Zinc & Iron & Manganese \\
\hline Control & & $11.89 \pm 1.06$ & $55.21 \pm 4.23$ & $143.16 \pm 6.01$ & $2.31 \pm 0.09$ \\
\hline \multirow{4}{*}{ 峁 } & 24 & $11.28 \pm 0.98$ & $51.16 \pm 3.06$ & $132.73 \pm 10.21$ & $2.18 \pm 0.18$ \\
\hline & 48 & $11.19 \pm 2.43$ & $46.81 \pm 7.91$ & $133.98 \pm 7.46$ & $2.20 \pm 0.18$ \\
\hline & 72 & $9.21 \pm 0.80^{*}$ & $38.37 \pm 4.82^{*}$ & $96.09 \pm 10.10^{*}$ & $2.25 \pm 1.01$ \\
\hline & 96 & $7.35 \pm 1.14^{*}$ & $33.21 \pm 2.21^{*}$ & $92.17 \pm 3.93 *$ & $2.23 \pm 0.30$ \\
\hline \multirow{4}{*}{ 㚄 } & 24 & $12.25 \pm 2.11$ & $54,23 \pm 2.72$ & $134.51 \pm 9.18$ & $2.24 \pm 1.61$ \\
\hline & 48 & $12.01 \pm 0.89$ & $52.09 \pm 1.31$ & $137.32 \pm 5.06$ & $1.93 \pm 0.27$ \\
\hline & 72 & $11.83 \pm 1.70$ & $53.16 \pm 4.21$ & $138.76 \pm 6.53$ & $1.93 \pm 0.30$ \\
\hline & 96 & $11.30 \pm 1.95$ & $49.76 \pm 3.81$ & $141.93 \pm 0.98$ & $2.05 \pm 0.94$ \\
\hline \multirow{4}{*}{ 总 } & 24 & $13.37 \pm 0.86^{*}$ & $52.16 \pm 7.28$ & $133.41 \pm 8.01$ & $2.24 \pm 0.87$ \\
\hline & 48 & $12.95 \pm 1.08$ & $50.35 \pm 3.74$ & $134.09 \pm 9.63$ & $2.15 \pm 1.11$ \\
\hline & 72 & $13.33 \pm 0.95^{*}$ & $51.61 \pm 1.02$ & $129.17 \pm 2.73^{*}$ & $2.13 \pm 1.09$ \\
\hline & 96 & $12.47 \pm 0.90$ & $49.91 \pm 3.34$ & $133.35 \pm 9.91$ & $2.16 \pm 0.61$ \\
\hline
\end{tabular}

$\mathrm{P}<0.05$, relative to control

Table 3: Comparative influences of EDTA, thiamin and ascorbic acid on the kidney levels of essential trace elements at 24, 48, 72 and 96 hours after treatment.

\begin{tabular}{|c|c|c|c|c|c|}
\hline \multirow{2}{*}{$\begin{array}{c}\text { Chelating } \\
\text { agent }\end{array}$} & \multirow{2}{*}{$\begin{array}{l}\text { Time interval } \\
\text { (hours) }\end{array}$} & \multicolumn{4}{|c|}{ Element level (ug/g dry weight ) } \\
\hline & & Copper & Zinc & Iron & Manganese \\
\hline Control & & $5.81 \pm 1.10$ & $39.26 \pm 0.92$ & $105.93 \pm 0.86$ & $1.38 \pm 0.27$ \\
\hline \multirow{4}{*}{ 芯 } & 24 & $3.50 \pm 0.84 *$ & $30.75 \pm 1.01^{*}$ & $104.65 \pm 1.33$ & $1.34 \pm 0.17$ \\
\hline & 48 & $3.16 \pm 0.94 *$ & $32.43 \pm 0.55^{*}$ & $98.35 \pm 1.09 *$ & $1.31 \pm 0.25$ \\
\hline & 72 & $2.92 \pm 0.19 *$ & $29.60 \pm 0.63 *$ & $97.49 \pm 2.18^{*}$ & $1.30 \pm 0.09$ \\
\hline & 96 & $4.37 \pm 1.16$ & $37.19 \pm 1.91$ & $100.22 \pm 2.89 *$ & $1.28 \pm 0.32$ \\
\hline \multirow{4}{*}{ 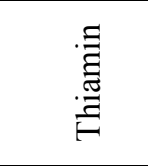 } & 24 & $4.69 \pm 0.80$ & $38.09 \pm 1.99$ & $105.13 \pm 2.11$ & $1.36 \pm 0.34$ \\
\hline & 48 & $4.13 \pm 0.64 *$ & $36.94 \pm 1.11^{*}$ & $99.81 \pm 1.14 *$ & $1.35 \pm 0.61$ \\
\hline & 72 & $4.97 \pm 1.59$ & $37.28 \pm 1.96$ & $103.93 \pm 2.23$ & $1.33 \pm 0.11$ \\
\hline & 96 & $5.16 \pm 1.60$ & $38.99 \pm 2.12$ & $105.70 \pm 2.12$ & $1.37 \pm 0.29$ \\
\hline \multirow{4}{*}{ 总 } & 24 & $3.48 \pm 0.90^{*}$ & $35.86 \pm 0.71^{*}$ & $104.39 \pm 1.37$ & $1.32 \pm 0.21$ \\
\hline & 48 & $3.55 \pm 0.67 *$ & $37.78 \pm 1.78$ & $100.91 \pm 0.80^{*}$ & $1.33 \pm 0.44$ \\
\hline & 72 & $4.38 \pm 1.09$ & $35.19 \pm 2.05^{*}$ & $100.85 \pm 1.46^{*}$ & $1.35 \pm 0.73$ \\
\hline & 96 & $4.39 \pm 1.03$ & $37.98 \pm 1.09$ & $103.98 \pm 2.11$ & $1.30 \pm 0.34$ \\
\hline
\end{tabular}

$\mathrm{P}<0.05$, relative to control

Table 4: Comparative influences of EDTA, thiamin and ascorbic acid on the muscle levels of essential trace elements at 24, 48, 72 and 96 hours after treatment.

\begin{tabular}{|c|c|c|c|c|c|}
\hline \multirow{2}{*}{$\begin{array}{c}\text { Chelating } \\
\text { agent }\end{array}$} & \multirow{2}{*}{$\begin{array}{c}\text { Time interval } \\
\text { (hours) }\end{array}$} & \multicolumn{4}{|c|}{ Element level (ug/g dry weight ) } \\
\hline & & Copper & Zinc & Iron & Manganese \\
\hline Control & & $7.16 \pm 0.88$ & $34.13 \pm 1.33$ & $31.08 \pm 2.95$ & $0.31 \pm 0.54$ \\
\hline \multirow{4}{*}{ 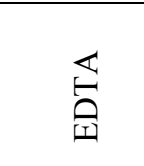 } & 24 & $6.52 \pm 0.62$ & $36.18 \pm 2.04$ & $28.78 \pm 3.15$ & $0.25 \pm 0.73$ \\
\hline & 48 & $6.70 \pm 0.67$ & $31.93 \pm 2.10$ & $30.06 \pm 1.36$ & $0.25 \pm 0.11$ \\
\hline & 72 & $5.39 \pm 0.13 *$ & $24.38 \pm 2.23 *$ & $19.28 \pm 3.19^{*}$ & $0.30 \pm 0.01$ \\
\hline & 96 & $4.17 \pm 0.80^{*}$ & $24.01 \pm 3.25^{*}$ & $23.51 \pm 3.41 *$ & $0.27 \pm 0.21$ \\
\hline \multirow{4}{*}{ 丞 } & 24 & $7.11 \pm 0.92$ & $34.01 \pm 2.39$ & $30.12 \pm 3.25$ & $0.31 \pm 0.03$ \\
\hline & 48 & $6.99 \pm 0.34$ & $34.12 \pm 3.12$ & $31.19 \pm 4.79$ & $0.31 \pm 0.13$ \\
\hline & 72 & $7.15 \pm 1.14$ & $32.45 \pm 1.94$ & $30.06 \pm 1.03$ & $0.30 \pm 0.15$ \\
\hline & 96 & $7.10 \pm 1.55$ & $33.07 \pm 3.41$ & $27.98 \pm 1.56$ & $0.27 \pm 0.11$ \\
\hline \multirow{4}{*}{ 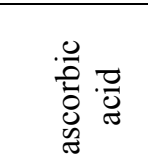 } & 24 & $6.89 \pm 0.41$ & $33.41 \pm 1.13$ & $29.11 \pm 1.36$ & $0.27 \pm 0.13$ \\
\hline & 48 & $6.91 \pm 1.28$ & $33.25 \pm 2.83$ & $29.63 \pm 1.06$ & $0.26 \pm 0.05$ \\
\hline & 72 & $8.67 \pm 3.11$ & $28.71 \pm 1.12 *$ & $29.81 \pm 3.17$ & $0.29 \pm 0.16$ \\
\hline & 96 & $10.13 \pm 1.02 *$ & $32.93 \pm 1.15$ & $25.29 \pm 1.85^{*}$ & $0.28 \pm 0.13$ \\
\hline
\end{tabular}

$\mathrm{P}<0.05$, relative to control

Among all chelating agents, EDTA produced comparatively more drastic effects on the tissue levels of endogenous essential trace elements. This was indicated by 
significant depletions in the blood, liver and muscle levels of copper, zinc and iron (72 and 96 hours) and renal levels of copper, zinc (24, 48 and72 hours) and iron (48, 72 and 96 hours). The fish treated with thiamin had lesser alterations in the levels of the essential trace elements than those treated with either EDTA or ascorbic acid. Thiamin caused significant depletion of hepatic manganese (48 and 72 hours) and renal levels of copper, zinc, and iron (48 hours), but in all cases with the exception of hepatic manganese values returned to nonnal control levels after 72 hours of treatment. Ascorbic acid statistically decreased the levels of renal zinc (24 and 72 hours), copper ( 24 and 48 hours) and iron (48 and 72 hours), blood iron (96 hours), hepatic iron, muscle zinc (72 hours), muscle iron (96 hours) and raised the levels of copper in liver (24 and 72 hours) and muscle copper (96 hours).

\section{DISCUSSION}

In developed countries, pollulant loads have increased with Econmic development sometimes exceeding the environmental capacity, which leads to significant pollution problems consequently, numerous environmental measurements have been introduced to reduced pollutant Loads (Yoshiak Tasvzuk 2010).

Comparison of the data of the present study reveals that trace element balance was greatly affected by EDTA followed by ascorbic acid, while it is less affected by thiamin. These chelating agents either individually or in combination have been proven to be effective in promoting the excretion of toxic metal ions from the body organs (Chisolm, 1978; Batton et al., 1981; Tandon and Flora, 1989; Ghazaly, 1991; Misra et al., 2008). The efficacy of the chelating agents to remove metals from the biological system depends on their ability to form stable complexes with the toxic metal ions and to enhance their excretion from the body without affecting the levels of essential trace elements (Misra et al., 2008).The high affinity of EDTA for copper, zinc and iron may be due to the high stability constants of copper, zinc and ironEDTA complexes in solution. This could explain the cause for the depletion of tissue copper, zinc and iron levels after EDTA administration. These data are inconsistent with those of Misra et al., (2008) who reported that EDTA has no effect on the trace metal content in rats.

The effect of EDTA was more pronounced than that of thiamin or ascorbic acid in depleting tissue levels of essential trace elements. Among the chelating agents evaluated in the present study, thiamin exhibited least potential to interact with endogenous trace elements as evidenced by nonaltered levels of the trace elements in the tissues. The low affinity of thiamin for the metals investigated herein may be due to the low stability constant of metal-thiamin complex in solution. The changes observed in the tissue metal concentrations of Tilapia florida after acute administration of the chelating agents points to the best efficacy of thiamin. Dhawan et al., (2015) observed that thiamin did not cause any major reduction in body metal content, but a combination of thiamin and ascorbic acid improved the ability of animals to excrete metals, thereby reducing the body metal content. Similarly, Bratton et al., (1981) found that thiamin had no effect on the trace metal content of plasma in cattle. In contrast, Flora et al., (1986); Tandon et al., (1984) and Tandon et al., (1987) observed that thiamin is effective in reducing the metal content. Analogues effects of ascorbic acid were reported by Calabrese and Kamp (1985). The present results seem to support the hypothesis that chelating agents may alter trace metal metabolism and are in general, consistent with those noted previously for other 
species (Torronen and marselos, 1978; Plana-Bohne, 1979; Milne and Omaye, 1980; Kostniak and Clarkson, 1981; Solecki et al., 1984; Tandon et al., 1984).

Marine water quality has become a matter of serious concern because of its effects on human health and aquatic ecosystem, including arich array of marine Life (Moore and Ramamoorsthy 2009).

\section{REFERENCES}

Batton, G. R.; Zmudzki, J.; Bell, M. C. and Warnock, L. G. (1981). Thiamin (Vitamin $\mathrm{B}_{1}$ ) effects on lead intoxication and deposition of lead in tissues. Theraptutic potential. Toxicol. Appl. Pharmacol., 59: 164-172.

Calabesese, E. D and Kamp, J. (1985). The effects of ascorbie acid supplementa lion on copper-induced oxidative changes in human erychoursocytes. J. Envirom. Sci. Halth, 20 (2):239-250.

Cantilena, L. R. Jr. and Klassen, C. D. (1982). Effect of chelating agents on the excretion of endogenous metais. Toxicol. Appl. Pharmacol., 63: 344-350.

Chisolm, J. J. (1978). The use of chelating agents in the treatment of acute and choursonic lead intoxication in childhood. J. Pediat., 73: 1-38.

Dhawan, M.; Kachoursu, D. N. and Tandon, S. K. (2015). Influence of thiamin and ascorbic acid supplementation of the antidotal efficacy of thiol chelators in experimental lead intoxication. Arch. Toxicol., 62:301-305.

Flora, S. J. S.; Singh, S. and Tandon, S. K. (1986). Chelation in metal intoxication XVIII : Combined effects of thiamin and calcium disodium versenate on lead toxicity. Life Sci., 38: 67-71.

Ghazaly, K. S. (1991). Influences of thiamin on lead intoxication, lead deposition in tissues and lead hematological responses of Tilapia zillii. Comp. Biochem. Physiol., 100(C): 417-421.

Kostyniak, P. L. and Clarkson, T. W. (1981). Role of chelating agents in metal toxicity. Fund. Appl. Toxicol., 1: 376-380.

Langmyher, F. J. and Amodt, J. (1976). Atomic absorption spectrophotometric determination of some metals. Analytica Chemiea Acta. 78: 483-486.

Milne, D. B. and Omaye, T. (1980). Effect of vitamin C on copper and iron metabolism in the guinea pig. Int. J. Vitam. Nutr. Res., 50: 301-308.

Misra, M.; athar, M.; Hasan, S. K. and Srivastave, R. C. (2008). Comparative effects of chelating drugs on trace metal and biochemical alterations in the rat. Bull. Environ. Contam. Toxicol., $41: 172-184$.

Moore. J. W. and Ramamoorsthy, S. (2009). Heavy metals in natural water. Springerver Lag, New York, 268p.

Planas-bohne, F. (1979). Influence of several chelating agents on the exoretion and organ concentration of copper in the rat. Toxieol. Appl. Pharmacol., 50:337345.

Rainbow, P. S. (2015). Trace metal concemtration in aquatic invertebrates: why and so what? Environmental pollution, 120:497-507.

Sigel, H. (1983). Zinc and its role in biology and nutrition. In: Metal Ions in Biological System, Marcel Dekker, New York, Vol. 15

Solecki, J. J.; Aviv, A. and Bogden, J. D. (1984). Effect of a chelating drug on balance and tissue distribution of four essential metals. Roxicol., $31: 207-216$.

Tandon, S. K. and Flora, S. J. S. (1989). Therapeutic efficacy of dimercaptosuccinic acid and thiamin / ascorbic acid on lead intoxication in rats. Bull. Environ. Contam. Toxicol., $43:$ 705-712. 
Tandon, S. K.; Flora, S.J.S. and Singh, S. (1987). Chelation in metal intoxication XXIV influence of various components of V vitamin B complex on therapeutic efficacy of disodium calcium versenate in lead intoxication. Pharmacol. Toxicol., 60: 62-67.

Tandon, S. K.; Jain, V. K. and Mathur, A. K. (1984). Effect of metal chelators on excretion and tissue levels of essential trace elements. Environ. Res., 35: 237245.

Torronen, R., and Marselos, M. (1978). Changes in the hepatic copper content after treatment with foreign compounds. Fin. Arch. Toxicol., 40: 247-249

Yoshiaki tsuzuki (2010). An index directy indicates Land-based pollutants load contributions of demostic waste water to the water pollution and its application. Sci of the Total Environment, 370 (2-3): 425-440.

\footnotetext{
ARABIC SUMMARY

دراسات فسيولوجية عن بعض العوامل القاتصة علي تراكم بعض العناصر الثقيلة في سمكة البلطي (تلابيا فلوريدا)

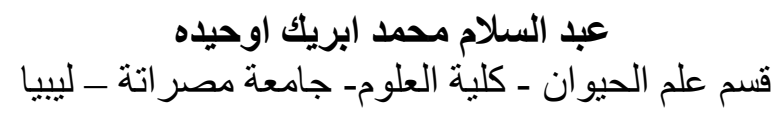

تم در اسة تأثثر ثلاثة مواد قانصة (الادتا، و الثيامين، وحمض الأسكوربيك) على تر اكم أربعة

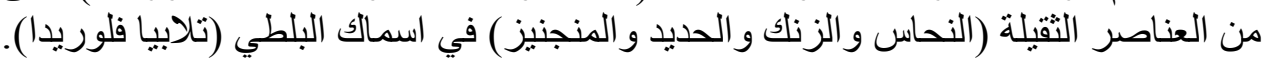

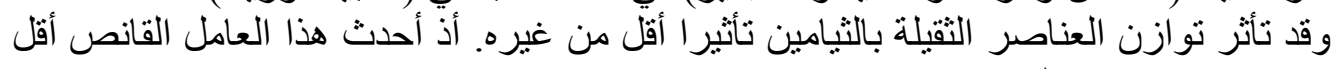
تغير ات في معدلات من هذه العناصر. تون العنرات في المقابل كانت التغير ات الحادنة التئة من استخدام الادتا أكثر وضوحاً من تلك الناتجة عن استخدام

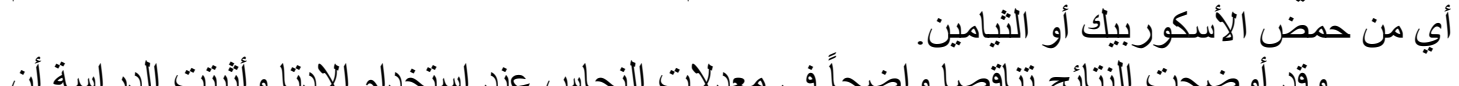

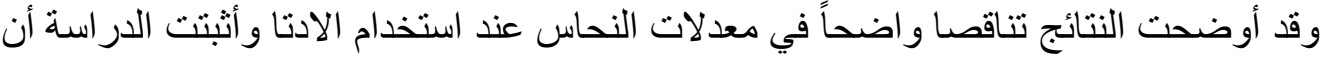
الثيامين لله كفاءة عاليه من بين العو امل القانصة الثناثة المختبرة.
} 